\title{
Comparison of commercial fibrin sealants in facelift surgery: a prospective study
}

This article was published in the following Dove Press journal:

Clinical, Cosmetic and Investigational Dermatology

6 November 2013

Number of times this article has been viewed

\author{
Giovanni Botti' \\ Michele Pascali ${ }^{2}$ \\ Chiara Botti' \\ Florian Bodog ${ }^{3}$ \\ Pietro Gentile ${ }^{2}$ \\ Valerio Cervelli² \\ 'Villa Bella Clinic, Salò, ${ }^{2}$ Department \\ of Plastic and Reconstructive Surgery, \\ University of Rome Tor Vergata, Italy; \\ ${ }^{3}$ University of Oradea, Oradea, \\ Romania
}

Correspondence: Pietro Gentile University of Rome Tor Vergata, San Salvatore in Lauro Place I5, 00186 Rome, Italy

Email pietrogentile2004@libero.it
Background: The aim of this study was to compare the effects of two types of fibrin glue in patients undergoing facelift surgery.

Methods: A prospective, controlled "right-left side" study was carried out in 20 patients. The two fibrin sealants used were Quixil ${ }^{\circledR}$ and Tissucol ${ }^{\circledR}$. The two sealants were used at the same time, ie, one on one side of the face and the other on the contralateral side. Comparisons were made with regard to rates of hematoma and seroma, degree of induration, edema, ecchymosis, pain levels, and patient satisfaction.

Results: The results were almost equivalent. The only exception was a significant $(40 \mathrm{~mL})$ hematoma in a patient treated with Quixil. Bleeding was most likely due to a sudden rise in blood pressure during the immediate postoperative period. However, it must be emphasized that, while Tissucol actually seals the undermined area, thus virtually eliminating the dead space, Quixil acts differently, in that its effectiveness in preventing hematoma is linked mainly to its hemostatic effect.

Conclusion: The two fibrin sealants used were nearly identical with regard to patient safety and quality of the result. Nevertheless, it is noted that, while Tissucol has both hemostatic and "gluing" effects, Quixil is mainly effective in securing hemostasis.

Keywords: facelift surgery, rhytidectomy, fibrin sealants, hematoma

\section{Introduction}

Fibrin sealants based on clottable plasma proteins ("fibrin glues") have several potential advantages in improving the outcome of facelift surgery. ${ }^{1}$ The use of fibrin sealants strongly hinders the formation of hematomas and seromas, allowing a faster recovery and return to daily activities, thus leading to higher postoperative patient satisfaction. ${ }^{2}$ Hematoma remains the most common complication in rhytidectomy, occurring in $0.3 \%-15 \%$ of cases. ${ }^{3-6}$ It can lead to tissue ischemia and skin necrosis, infection, prolonged facial edema, hyperpigmentation, scar retraction, and need for further surgery to evacuate and drain the hematoma and/or correct its consequences, the result being decreased patient satisfaction. ${ }^{7}$ Further, addition of fibrin sealants has eliminated the routine use of drains in the majority of cases. Drains are expensive, cumbersome and occlusive, time-consuming to position and remove, and may be annoying for patients, so the preference to eliminate them is a reasonable one. ${ }^{8}$

Fibrin sealants are mostly derived from plasma components. Most commercially available products contain purified, virally deactivated human fibrinogen and thrombin, with different quantities of factor XIII, antifibrinolytic agents, and calcium chloride. ${ }^{9}$ When fibrinogen and thrombin are mixed, the fibrinogen component is converted to 
fibrin monomers. ${ }^{10}$ The fibrin network is thought to reduce the amount of postoperative bleeding by sealing capillary vessels and making raw surfaces adhere to one another, ${ }^{7}$ thus closing the dead space. Premature clot lysis by fibrin sealants is prevented by supplementation with fibrinolysis inhibitors, such as aprotinin or tranexamic acid. The aerosolizing apparatus incorporated in the kit allows for even distribution of the glue as a hemostatic and sealing agent, thus limiting clumping. ${ }^{2}$

While the composition of most fibrin sealants is similar, different formulations and varying concentrations of key components give rise to variations in the properties of the clots formed. ${ }^{9}$ Important parameters, including speed of clot formation, adhesive and tensile strength, efficacy in arresting bleeding, and clot durability may be affected.

In September 1989, the authors reported their first experience using a fibrin sealant in 40 consecutive facelifts, documenting a reduction in the rate of hematoma to $1 \%$, compared with a rate of $25 \%$ for facelifts performed without fibrin sealants in earlier years. ${ }^{11}$ The only fibrin sealant available on the market at that time was Biocol glue (BioTransfusion, Lille, France). In the second half of the 1990s, fibrin sealants had almost ceased to be used, mostly because of the (theoretical) risk of viral and prion transmission. However, no such case has ever been documented in millions of applications of fibrin sealant. ${ }^{12}$ The authors began to use the product again in 2008 , systematically employing a fibrin sealant in all patients undergoing facelift surgery. The glue used was Quixil ${ }^{\circledR}$ (Johnson and Johnson, Raritan, NJ, USA), and from 2008 through 2010 a case series of some 150 facelifts was built.

Nonetheless, wishing to test the characteristics of other fibrin sealants available on the market, the authors undertook a prospective study in 20 cases of facelift surgery performed from June through October 2010. These patients were treated using two different fibrin sealants at the same time, one on one side of the face and the other on the contralateral side. The left side of the rhytidectomy was treated with Tissucol ${ }^{\circledR}$ (Baxter, Deerfield, IL, USA) and the right side with Quixil. To our knowledge, this is the first study comparing the simultaneous effects of two types of fibrin glue, one on each side of the same face.

\section{Materials and methods}

A prospective study was conducted in 20 patients (14 women and six men) undergoing facelift surgery from June to October 2010. The mean patient age was 56 (range 43-72) years. The patients signed informed consent documents according to the guidelines of the local committee on human research, enabling them to both undergo the procedure and be included in the study.

Exclusion criteria were both local and systemic. Systemic exclusion criteria included platelet disorders, thrombocytopenia, antiaggregating therapy, uncompensated diabetes, sepsis, and heavy use of tobacco. Local exclusion criteria included previous facelift, basal cell carcinoma, and squamous cell carcinoma. Genetic disorders were not considered to be an exclusion criterion. Subjects eligible for inclusion were nonsmokers and smokers of less than 10 cigarettes per day, patients who accepted the contralateral controlled study design, and not aged over 75 years old.

All patients underwent facelift surgery with superficial muscular aponeurotic system undermining and imbrication, whereby the skin dissection was carried out for about $5 \mathrm{~cm}$ from the classical periauricular incision, while the subsuperficial muscular aponeurotic system undermining was further extended for another $4 \mathrm{~cm}$ in both the cheek and the neck area. The surgeon carried out hemostasis with extreme care. The composite flap thus formed (skin, fat and platysma, and cheek superficialis fascia) was lifted and anchored to fixed points (mastoid periosteum, Lore's fascia, periosteum of the posterior third of the zygomatic arch, and deep temporal fascia). Key preauricular and postauricular sutures were then applied, the excess skin was removed, and fibrin glue was applied for 15-20 seconds on average, with application of manual pressure for 3 minutes, followed by use of absorbable subcuticular sutures (Figures 1 and 2). Five patients underwent mid facelift surgery at the same time.

Two commercially available fibrin sealants were compared in this study, ie, Quixil and Tissucol. The fibrinogen

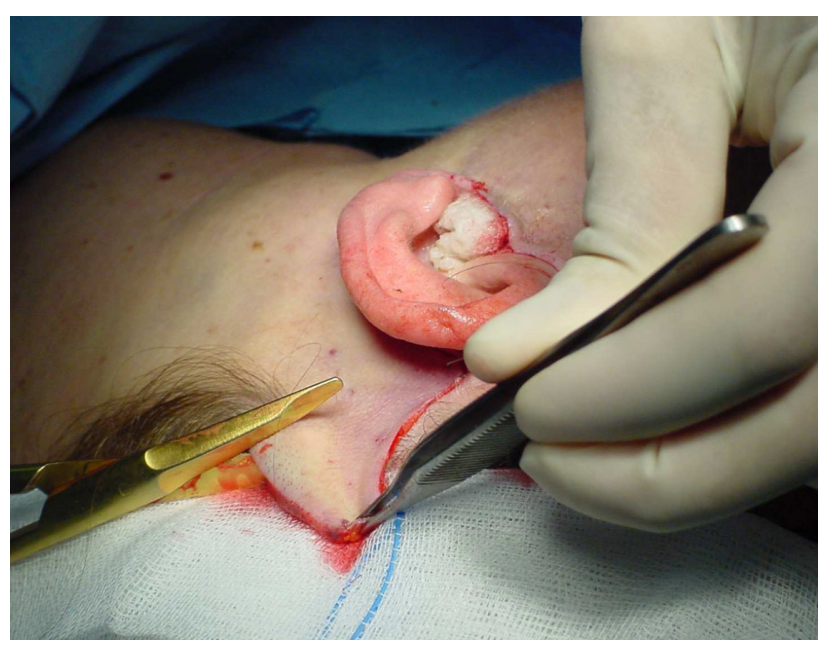

Figure I Excess skin is removed. 


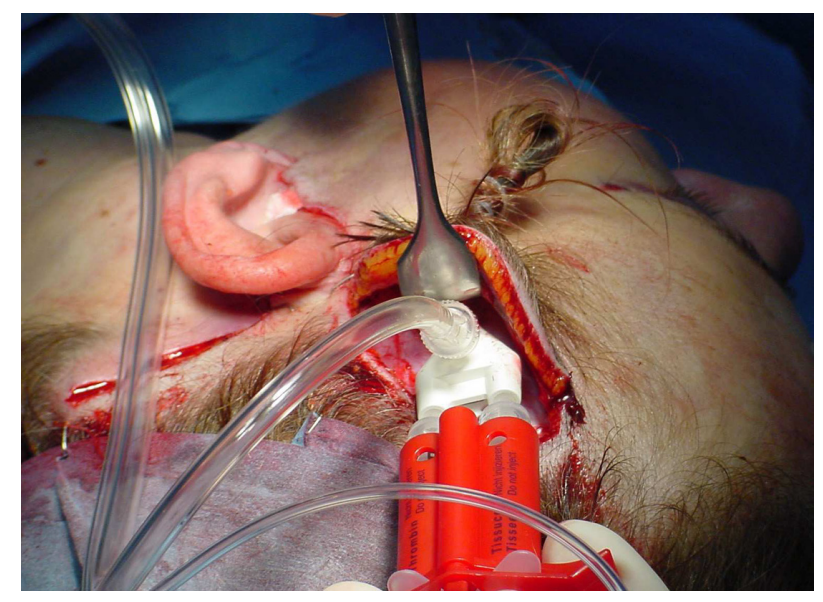

Figure 2 Intraoperative photograph of fibrin glue in dual-jet sprayer being aerosolized under skin flaps and on top of the superficial muscular aponeurotic system. Note that the fibrin sealant is applied after application of key sutures and removal of excess skin.

component of Tissucol is lyophilized and heated with a controlled moisture content ("vapor-heated"). In contrast, the fibrinogen component of Quixil is derived from a largepool cryoprecipitate.

Quixil is formulated with tranexamic acid as the antifibrinolytic agent, whereas the other sealant is formulated with aprotinin. The salient differences in the composition of these two sealants are listed in Table 1.

The products were prepared according to the manufacturers' instructions and then sprayed in aerosol form in the subcutaneous plane, already reduced after repositioning of the superficial muscular aponeurotic system, on the raw dissected surfaces in the periauricular region, neck included (Figure 2). In all cases, the left side of the rhytidectomy was treated using Tissucol and the right side with Quixil. The amount of glue used was $2 \mathrm{~mL}$ per side. After the glue was sprayed, the excess was squeezed out through the skin incision and removed (Figure 3). Gentle external pressure was applied using moist gauze for 3 minutes to the flaps. No drains were used. In order to maintain constant moderate compression, a light protective dressing was applied for 8 hours, after which it was removed (usually in the late afternoon) to check that no blood had collected (Figures 4 and 5).

Comparisons were made with regard to hematoma and seroma rates, degree of induration, edema, and ecchymosis, pain levels, and patient satisfaction (Tables 2 and 3). The patients were monitored at 8 and 24 hours, 3 and 15 days, and 3 months after surgery, and photographs were taken (only the area of the rhytidectomy to which the glue had been applied was examined, disregarding the mid facelift zone). In order to assess the effectiveness of the two glues, cases of hematoma (reporting in milliliters the exact amount of blood collected), seroma, induration, edema, and ecchymosis were recorded. Two visual analog scale sheets were distributed to the patients one week after surgery for assessment of pain and satisfaction with the procedure.

\section{Results}

The results of this study, performed in 20 patients ( 14 women and six men) with an age range of 43-72 (mean 56) years using two different types of fibrin sealant on both sides of the face, were equivalent, as shown in Table 2. The only exception was a significant $(40 \mathrm{~mL})$ hematoma on the right (Quixil) side in one patient. This hematoma was found when the dressing was removed 8 hours after surgery. This male patient was taken back to theater, where the arteriole responsible for the bleeding was identified and quickly cauterized. The bleeding was most probably due to a sudden rise in blood pressure during the immediate postoperative period. In fact, postoperative blood pressure rose to $180 / 100 \mathrm{mmHg}$ in this patient on awakening from general anesthesia.

After 24 hours, no hematomas of note had occurred in the remaining 19 patients, although small pools of blood (2-4 mL, Table 2) were present in two cases that were easily aspirated using an 18-gauge needle mounted on a $10 \mathrm{cc}$ syringe. These two cases of small hematoma occurred on sides of the face treated with Tissucol. However, the resulting difference between the two sides of the face in terms of milliliters of blood removed was not statistically significant

Table I Details of fibrin sealants compared in the studies

\begin{tabular}{|c|c|c|c|c|c|c|c|c|}
\hline Product & $\begin{array}{l}\text { Thrombin } \\
\text { IU/mL }\end{array}$ & $\begin{array}{l}\text { Fibrinogen } \\
\mathrm{mg} / \mathrm{mL}\end{array}$ & $\begin{array}{l}\alpha-\gamma \text { or } \alpha \\
\text { fibrinogen } \\
\text { polymers }\end{array}$ & $\begin{array}{l}\text { Factor XIII } \\
\text { activity } \mathrm{U} / \mathrm{mL}\end{array}$ & $\begin{array}{l}\text { Virus } \\
\text { inactivation }\end{array}$ & $\begin{array}{l}\text { Fibronectin } \\
\mathrm{mg} / \mathrm{mL}\end{array}$ & $\begin{array}{l}\text { Antifibrinolytic } \\
\text { agent }\end{array}$ & $\begin{array}{l}\text { Device/ } \\
\text { applicator }\end{array}$ \\
\hline Tissucol $^{\circledR}$ & 500 & $70-110$ & Not present & $10-50$ & $\begin{array}{l}\text { "Vapor } \\
\text { heating" after } \\
\text { lyophilization }\end{array}$ & $<5$ & Aprotinin & $\begin{array}{l}\text { Duploject } \\
\text { spray set }\end{array}$ \\
\hline Quixil $^{\circledR}$ & $800-1,200$ & $40-60$ & $\begin{array}{l}\text { Present at more } \\
\text { than } 10 \% \text { of total } \\
\text { protein }\end{array}$ & $2-20$ & $\begin{array}{l}\text { Solvent } \\
\text { detergent and } \\
\text { pasteurization }\end{array}$ & $1-12$ & $\begin{array}{l}\text { Tranexamic } \\
\text { acid }\end{array}$ & $\begin{array}{l}\text { Triple lumen } \\
\text { catheter }\end{array}$ \\
\hline
\end{tabular}




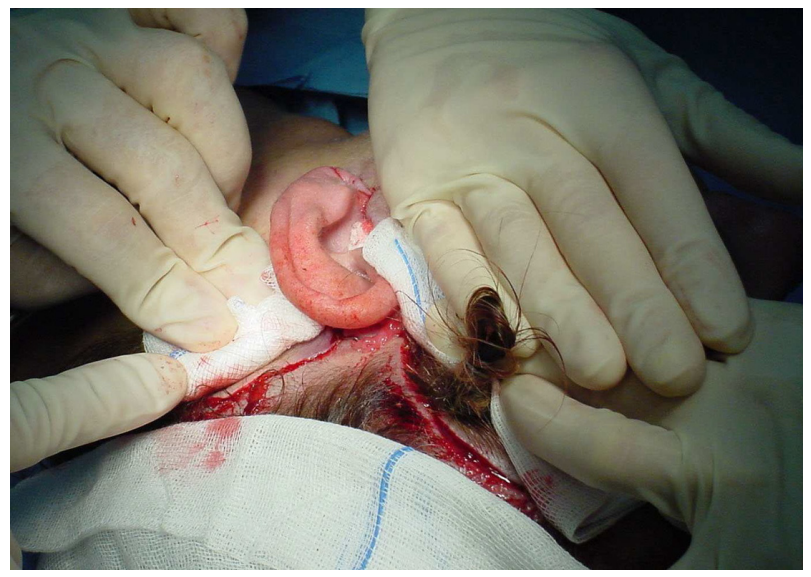

Figure 3 Excess glue is squeezed out from the dissected area through the skin incision and eliminated.

( $P=0.357$, paired $t$-test). No cases of seroma or induration were observed, with only one bilateral case of slight ecchymosis and another bilateral case of moderate edema (more than the light usual one). The results are shown in Figures 6-9.

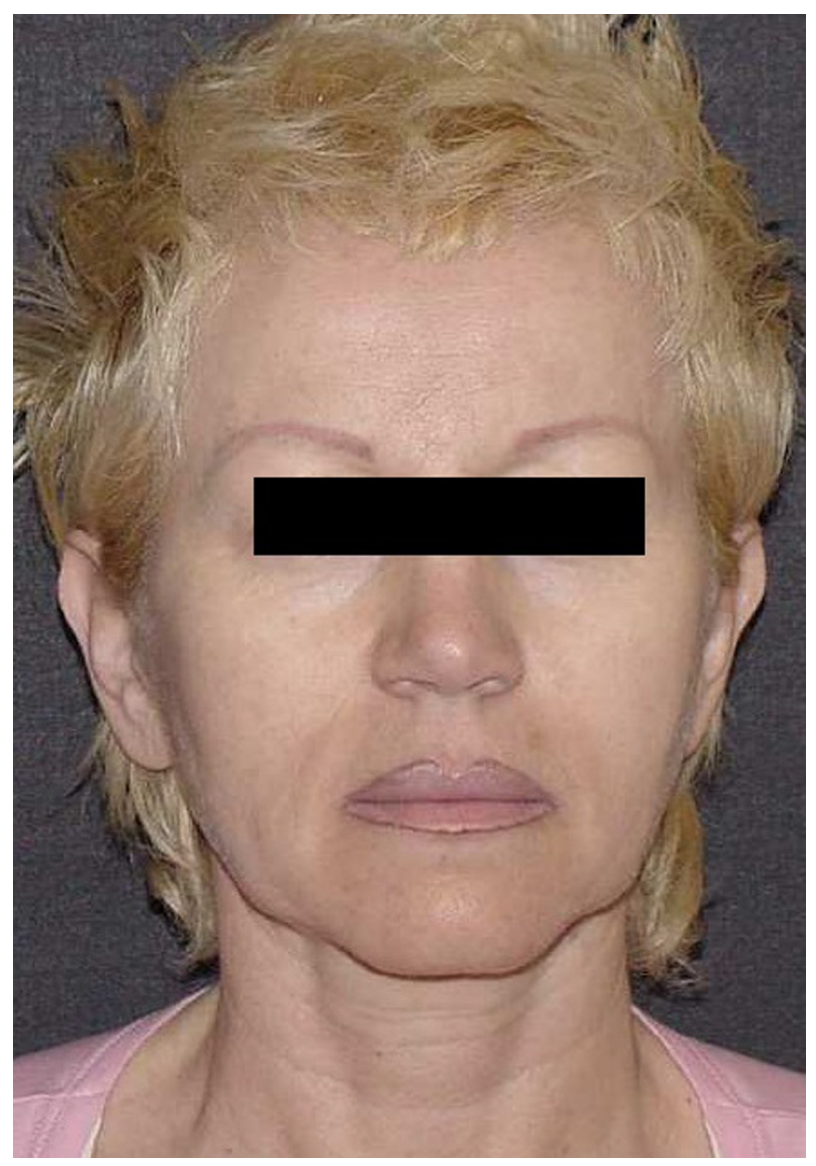

Figure 4 Image of a 55-year-old woman who has undergone facelift and upper blepharoplasty.

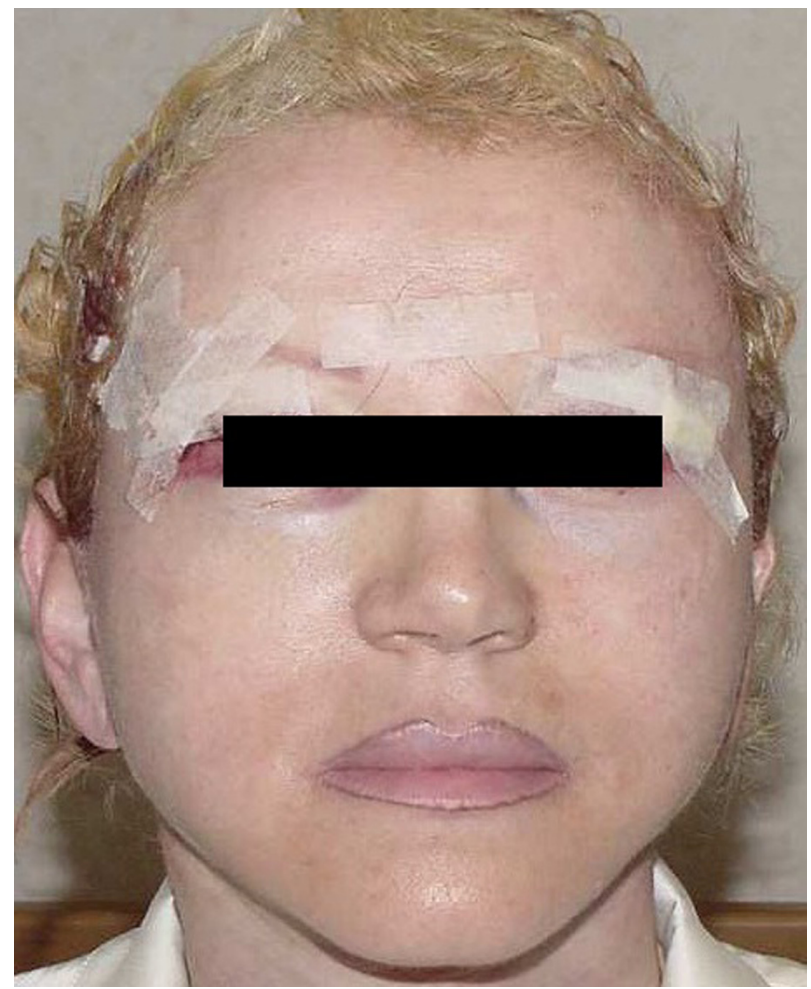

Figure 5 Appearance at 6 hours postoperatively with no drain placement.

When patients were asked to point out their levels of pain and satisfaction on a $10 \mathrm{~cm}$ line, they indicated mean bilateral scores of approximately 3 for pain and 9 for satisfaction. The differences between the two sides (ie, for the two glues, reported in Table 3) were not statistically significant for pain $(P=0.952$, Wilcoxon signed-rank test) or satisfaction $(P=0.374)$.

The only significant difference reported by the surgeon was in the degree of adhesiveness of the two-fibrin glues used. While Tissucol brings about almost instantaneous sealing, making it difficult to "reopen" the skin flap just glued, Quixil does not provide prompt adhesion of the flap, not even in the first minutes after application.

The ability of the two fibrin sealants to prevent hematoma, ecchymosis, and edema was found to be identical. The authors

Table 2 Complications of the procedure

\begin{tabular}{lll}
\hline Complication & Tissucol $^{\circledR}$ (left side) & Quixil $^{\circledR}$ (right side) \\
\hline Hematoma & One case, $1 \mathrm{~mL}$ & One case, $40 \mathrm{~mL}$ \\
& One case, $2 \mathrm{~mL}$ & \\
Seroma & No cases & No cases \\
Induration & No cases & No cases \\
Edema & One case & One case \\
Ecchymosis & One case & One case \\
\hline
\end{tabular}


Table 3 Patient scores as indicated on a visual analog scale of pain and satisfaction related to each side of the face

\begin{tabular}{|c|c|c|c|c|}
\hline \multirow[t]{2}{*}{ Patient } & \multicolumn{2}{|c|}{$\begin{array}{l}\text { VAS score for pain } \\
\text { ( } 0 \text { maximum pain, } \\
\text { I } 0 \text { no pain) }\end{array}$} & \multicolumn{2}{|c|}{$\begin{array}{l}\text { VAS score } \\
\text { for satisfaction } \\
(0 \text { minimum, } \\
\text { (0 maximum })\end{array}$} \\
\hline & $\begin{array}{l}\text { Tissucol }^{\circledR} \\
\text { (left side) }\end{array}$ & $\begin{array}{l}\text { Quixil }^{\circledR} \\
\text { (right side) }\end{array}$ & $\begin{array}{l}\text { Tissucol } \\
\text { (left side) }\end{array}$ & $\begin{array}{l}\text { Quixil } \\
\text { (right side) }\end{array}$ \\
\hline I & 8.0 & 7.5 & 9.5 & 9.2 \\
\hline 2 & 7.2 & 7.6 & 8.4 & 8.6 \\
\hline 3 & 9.2 & 9.4 & 9.5 & 9.7 \\
\hline 4 & 8.5 & 8.4 & 9.3 & 8.9 \\
\hline 5 & 7.2 & 7.5 & 8.7 & 9.2 \\
\hline 6 & 9.1 & 9.5 & 9.8 & 10.0 \\
\hline 7 & 6.9 & 7.6 & 8.4 & 9.4 \\
\hline 8 & 8.5 & 8.0 & 8.5 & 8.4 \\
\hline 9 & 9.1 & 7.2 & 8.5 & 8.4 \\
\hline 10 & 8.8 & 9.1 & 9.1 & 9.3 \\
\hline II & 7.7 & 7.4 & 8.6 & 8.8 \\
\hline 12 & 8.3 & 8.2 & 8.4 & 8.9 \\
\hline 13 & 7.2 & 6.9 & 10.0 & 10.0 \\
\hline 14 & 9.2 & 8.7 & 8.3 & 9.1 \\
\hline 15 & 7.4 & 7.9 & 8.9 & 9.2 \\
\hline 16 & 7.6 & 7.6 & 8.4 & 9 \\
\hline 17 & 9.4 & 9.2 & 8.7 & 8.2 \\
\hline 18 & 8.4 & 8.8 & 8.8 & 8.9 \\
\hline 19 & 9.8 & 9.9 & 9.9 & 9.5 \\
\hline 20 & 7.5 & 7.3 & 9.6 & 9.3 \\
\hline Mean \pm SD & $8.3 \pm 0.9$ & $8.2 \pm 0.9$ & $9.0 \pm 0.6$ & $9.1 \pm 0.5$ \\
\hline$P$ & 0.952 & & 0.374 & \\
\hline
\end{tabular}

Notes: The last two rows show the mean \pm SD and $P$-value evaluated by the Wilcoxon signed-rank test.

Abbreviation: SD, standard deviation.

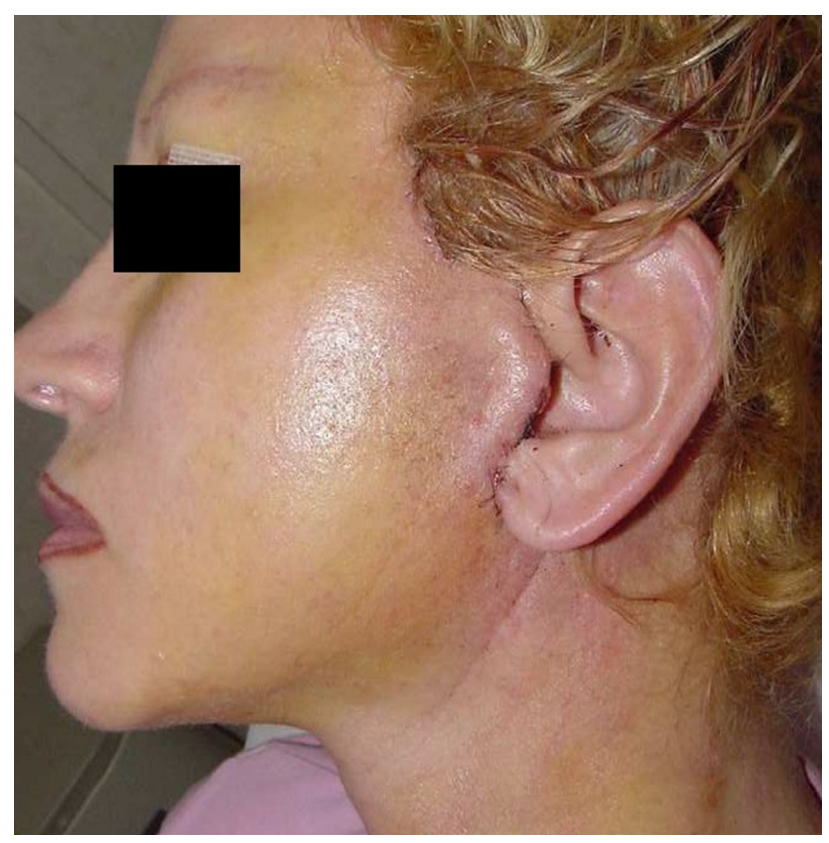

Figure 6 Appearance 3 days postoperatively after removal of eyelid sutures.

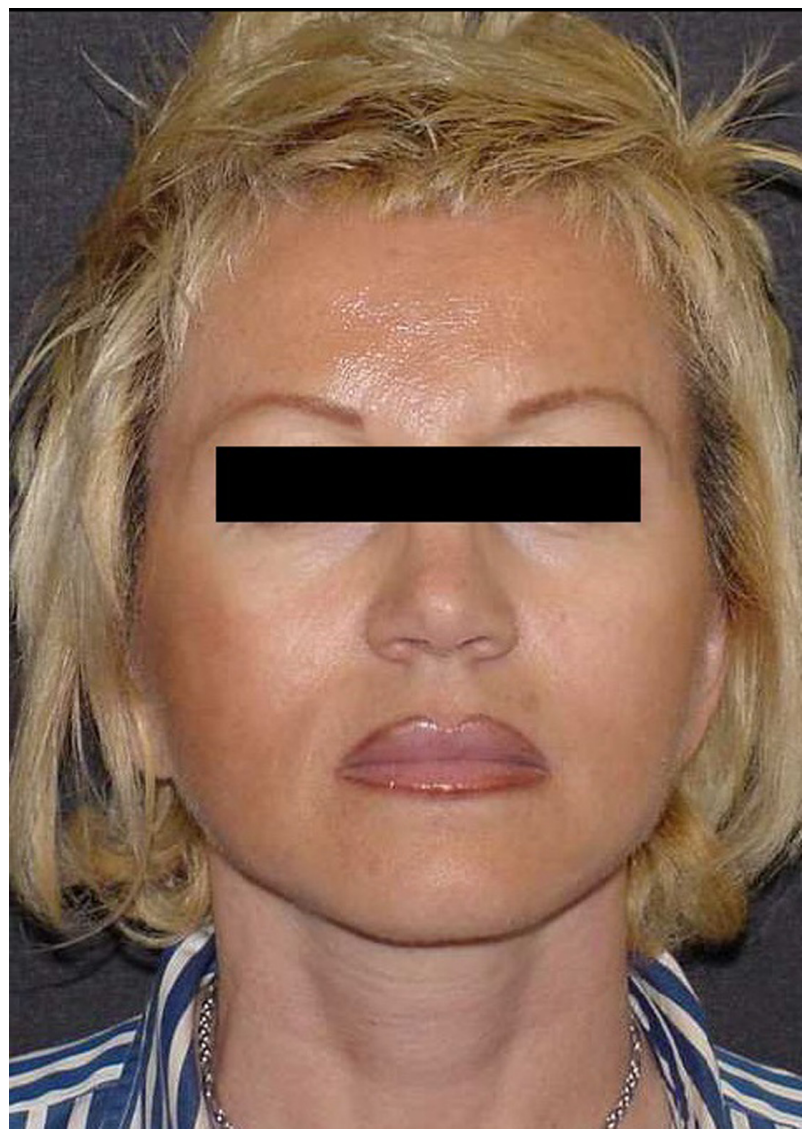

Figure 7 Appearance 10 days postoperatively in frontal view.

can confirm that systematic use of these sealants in facelift surgery is important both for patient safety and for the quality of the final result.

\section{Discussion}

Aerosolized fibrin sealant or "glue" provides several potential advantages in improving the outcome of facelift surgery. ${ }^{8}$ A number of studies have investigated the effectiveness of fibrin glues in reducing the formation of hematoma, seroma, and ecchymosis in rhytidectomy. ${ }^{1,7,8,13-15}$ In addition, a reduction in postoperative wound drainage is important because it greatly influences patient comfort and reduces recovery time.

While the composition of most fibrin sealants is similar, different formulations and varying concentrations of key components have given rise to variations in the properties of the clots formed. ${ }^{9}$ Many factors affect the rate and extent of fibrin polymerization and, ultimately, the structure of the clot. These include the concentrations of fibrinogen and thrombin (commercially available preparations contain $80-100 \mathrm{mg} / \mathrm{mL}$ and $4-1,000 \mathrm{IU} / \mathrm{mL}$, respectively), 


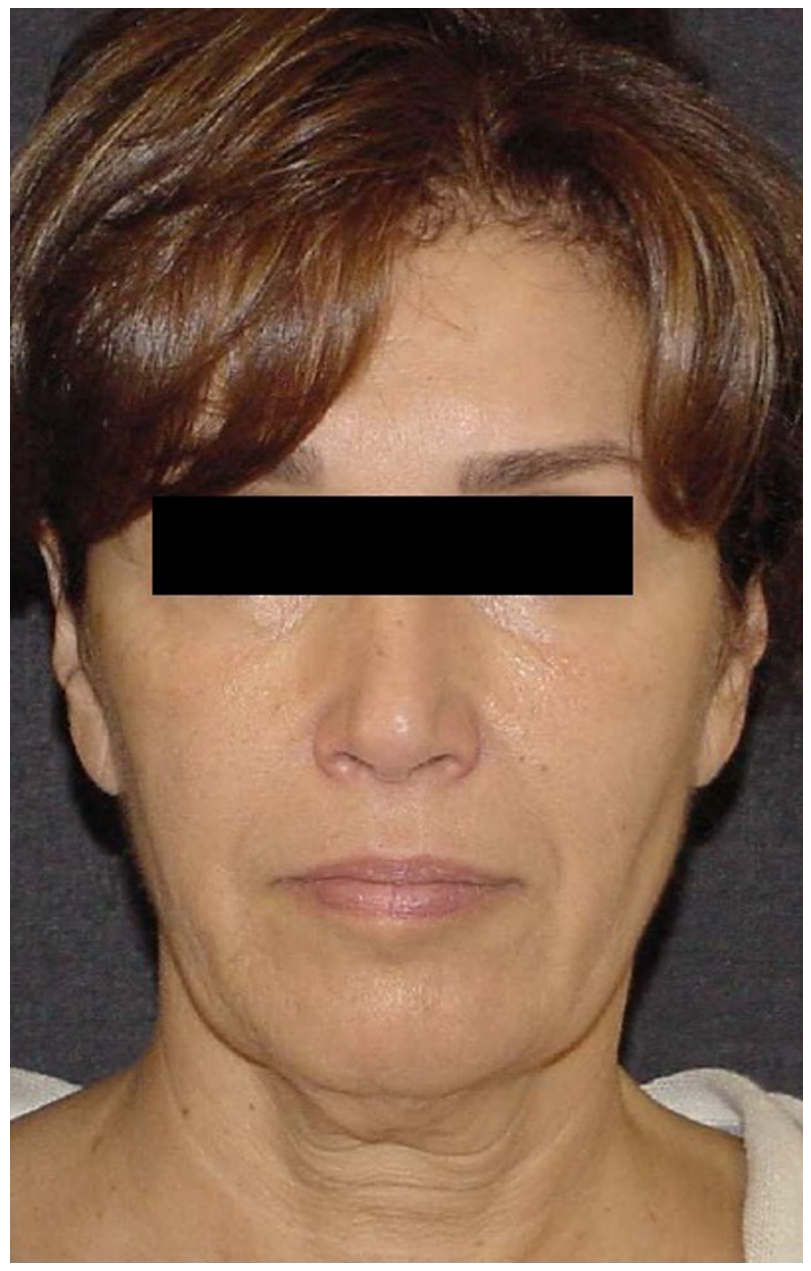

Figure 8 Image of a 48-year-old woman who underwent facelift surgery.

presence of other plasma proteins, calcium concentration, ionic strength, and temperature. ${ }^{16}$ Commercially available fibrin sealants utilizing aprotinin or tranexamic acid have a different visual appearance (nontransparent for aprotinin versus transparent for tranexamic acid) and different sealing efficacy. ${ }^{17}$ Few comparative data are available on the commercially available fibrin sealants regarding their ability to achieve hemostasis or their sealing efficacy. ${ }^{9}$

In an interesting study, Furst et a $1^{17}$ compared the influence of tranexamic acid and aprotinin as fibrinolysis inhibitors on the structure, mechanical properties, and cytocompatibility of fibrin matrices. In an in vivo partial lung resection model, Quixil showed significantly less sealing efficacy than fibrin sealants utilizing aprotinin. The authors also demonstrated that tranexamic acid alters the macroscopic appearance as well as microscopic three-dimensional structures, and reduces the tensile strength and cytocompatibility of fibrin matrices. Reduced tensile strength correlated with a change from coarse physiological clots to fine nonphysiological clots,

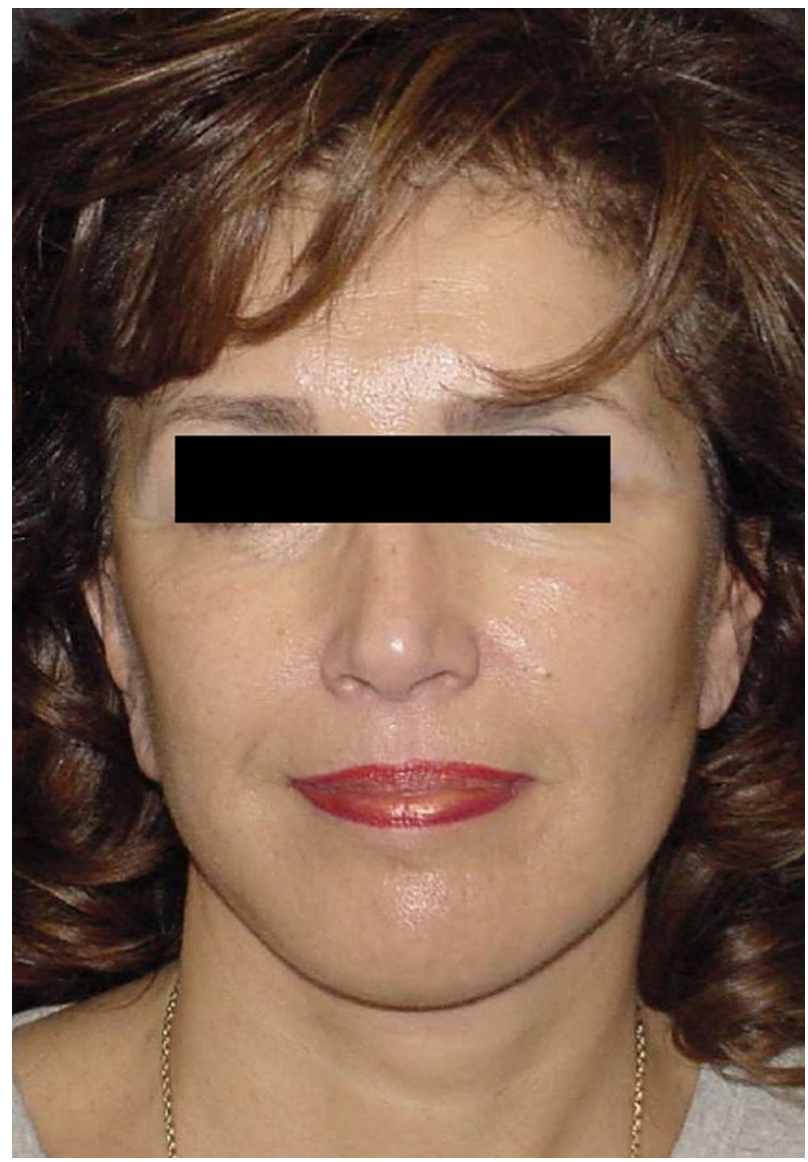

Figure 9 Appearance 15 days postoperatively. The two different types of fibrin glue were used on the two sides of the face with comparable results.

which became macroscopically transparent and microscopically characterized by thinner fibrin fibers, more branching points, and reduced pore size.

Dickneite et $\mathrm{al}^{9}$ reported the results of several in vitro and in vivo studies comparing the properties of 12 different commercially available fibrin sealants. The results indicated clear differences, both in the adhesive properties of the resulting clot and in terms of maximizing the likelihood of early hemostasis and minimizing the risk of rebleeding. Quixil showed significantly less adhesive strength and formed a relatively soft clot. This reflects the low fibrinogen and factor XIII content of this fibrin sealant. Nur et a ${ }^{18}$ did a study using a rabbit partial liver resection model to determine the hemostatic effectiveness of three common fibrin sealants, ie, Quixil, Tissucol, and Beriplast ${ }^{\circledR}$ (CSL Behring, King of Prussia, PA, USA). Bleeding time, blood loss, and volume of sealant used in this rabbit model were inversely correlated with the thrombin concentration in the sealant. In direct comparisons with Tissucol and Beriplast, Quixil was associated with the shortest bleeding time, the lowest volume of sealant used, and the lowest score for adhesions. The high thrombin 
component (1,000 IU/mL) of Quixil accelerates coagulation of the fibrinogen-containing component and probably also of the clottable proteins in blood present at the injury site.

Differences in source materials, processing, and composition of the two fibrinogen-containing components influenced the rapidity and durability of attachment of the sealant to the underlying tissue. ${ }^{19}$ Two fibrinogen preparations, each an intermediate in the manufacture of the "fibrinogen" component of a commercial human tissue sealant, were made from a common cryoprecipitate source. The first preparation, formulated according to the process described by Schwarz et $\mathrm{al}^{20}$ (the same method as that used in the production of Tissucol) had a higher ratio of clottable to total protein than did the second, which was formulated according to the method described by Martinowitz and $\mathrm{Bal}^{21}$ (used in the production of Quixil), but at a much lower fibronectin to fibrinogen ratio.

Bar et $\mathrm{al}^{22}$ demonstrated that efficient binding of a fibrin sealant clot to collagen depends on a significant concentration of cross-linked fibrinogen-fibronectin molecules in the fibrinogen component of the sealant. These authors concluded that the high collagen-binding capacity of the Martinowitz fibrinogen (using Quixil) might improve adhesion of tissue sealant clots to the extracellular matrix.

Strong adhesion between injured tissue and adjacent tissues is certainly a major surgical concern, ${ }^{18}$ but it is just as important to obtain early hemostasis as it is to minimize the risk of rebleeding. The results obtained by the authors of this study were equivalent for the two sides of the face treated with the two different fibrin sealants. Therefore, the equivalent effectiveness of the two fibrin sealants was demonstrated in preventing the formation of hematomas, which are the most frequent complications of facelift surgery.

Obviously, a single patient treated with Quixil developing hematoma on the right side is not enough to draw the conclusion that this product is less effective than Tissucol in preventing collection of blood. In fact, the cause of this hematoma was almost certainly related to a sudden rise in blood pressure during the immediate postoperative period. This was confirmed by the high blood pressure values registered.

With regard to the speed of attachment of the sealant to the underlying tissue and thus its adhesive capacity, the authors noticed a significant difference between the two tested products. Whereas Tissucol brings about nearinstantaneous adhesion, making it difficult to raise the skin flap, which was glued to the underlying tissues, Quixil did not show the same immediate adhesive capacity. Perhaps, given time, adhesion similar to that obtained with Tissucol may occur; however, it was certainly easy to verify that, during the initial minutes following its application, the skin flap could be raised easily and with minimal resistance, almost as if no glue had been used.

There are data demonstrating differences in the degree of adhesiveness of these two fibrin sealants, even during the first few days following surgery, ${ }^{23,24}$ and indicating that adhesions are caused mainly by postoperative oozing of blood beneath the physical barrier of the initial seal. Any moderate immediate leakage of blood as a result of less efficient hemostasis during surgery will promote scar retraction. The seal obtained with Quixil theoretically appears to be more secure postoperatively, resulting in a lower incidence and less severity of rebleeding. This means a significant reduction in formation of postoperative adhesions. This has led to the hypothesis that the greater adhesive capacity shown by Tissucol immediately after its application continues during the following hours, stably gluing the skin flap to the underlying tissues and thus eliminating any dead space.

On the other hand, the excellent hemostatic effect of Quixil, which maximizes the possibility of early hemostasis and minimizes the risk of rebleeding, was probably also protracted for a long time after its application, thus obtaining similar results in the prevention of blood pooling. Tranexamic acid (contained in Quixil) is a low molecular weight antifibrinolytic agent that is incorporated into thrombus and protects it from lysis during the postoperative period. ${ }^{25}$ Antifibrinolytic agents of higher molecular weight, eg, aprotinin, are less efficiently incorporated into thrombus and delay the healing process by remaining at the site of thrombus for longer. ${ }^{18}$

\section{Disclosure}

None of the authors has a financial interest in any of the products, devices, or drugs mentioned in this paper.

\section{References}

1. Oliver DW, Hamilton SA, Figle AA, Wood SH, Lamberty BG. A prospective, randomized, double-blind trial of the use of fibrin sealant for face lifts. Plast Reconstr Surg. 2001;108:2101-2105.

2. Matarasso A, Rizk SS, Markowitz J. Short scar facelift with the use of fibrin sealant. Dermatol Clin. 2005;23:495-504.

3. Rees TD, Barone CM, Valauri FA, Ginsberg GD, Nolan WB 3rd. Hematomas requiring surgical evacuation following face lift surgery. Plast Reconstr Surg. 1994;93:1185-1190.

4. Perkins SW, Williams JD, Macdonald K, Robinson EB. Prevention of seromas and hematomas after face lift surgery with the use of postoperative vacuum drains. Arch Otolaryngol Head Neck Surg. 1997;123:743-745.

5. Adamson P, Moran M. Complications of cervicofacial rhytidectomy. Plast Surg Clin North Am. 1993;1:257.

6. Kamer FM, Song AU. Hematoma formation in deep plane rhytidectomy. Arch Facial Plast Surg. 2000;2:240-242. 
7. Zoumalan R, Rizk RZ. Hematoma rates in drainless deep-plane facelift surgery with and without the use of fibrin glue. Arch Facial Plast Surg. 2008; 10:103-107.

8. Fezza JP, Cartwright M, Mack W, Flaharty P. The use of aerosolized fibrin glue in facelift surgery. Plast Reconstr Surg. 2002;110:658-664.

9. Dickneite G, Metzner H, Pfeifer T, Kroez M, Witzke G. A comparison of fibrin sealants in relation to their in vitro and in vivo properties. Thromb Res. 2003;112:73-82.

10. Mosesson MW. Fibrin polymerization and its regulatory role in hemostasis. J Lab Clin Med. 1990;116:8-17.

11. Botti G. Ripristino rapido della vita di relazione dopo intervento di lifting cervico-facciale. [Rapid restoration of social life after surgery facelift and neck]. Proceedings 36th National Congress SICPRE. Messina, Italy: Monduzzi Publisher; 1989.

12. Mooney E, Loh C, Pu LL, et al. The use of fibrin glue in plastic surgery. Plast Reconstr Surg. 2009;124:989-992.

13. Marchac D, Greensmith AL. Early postoperative efficacy of fibrin glue in face lifts: a prospective randomized trial. Plast Reconstr Surg. 2005;115:911-918.

14. Kamer FM, Nguyen DB. Experience with fibrin glue in rhytidectomy. Plast Reconstr Surg. 2007;120:1045-1051.

15. Lee S, Pham AM, Pryor SG, Tollefson T, Sykes JM. Efficacy of Crosseal fibrin sealant (human) in rhytidectomy. Arch Facial Plast Surg. 2009;11:29-33.

16. Okada M, Blomback B. Factors influencing fibrin gel structure studied by flow measurement. Ann N Y Acad Sci. 1983;408:233-253.

17. Furst W, Banerjee A, Redl H. Comparison of structure, strength and cytocompatibility of a fibrin matrix supplemented either with tranexamic acid or aprotinin. J Biomed Mater Res B Appl Biomater. 2007;82:109-114.
18. Nur I, Lyahovetsky Y, Bar L, Schon M. Commercial fibrin sealants are not equivalent in a rabbit liver-resection model which quantitatively evaluates hemostasis and formation of adhesions. Eur Surg Res. 2005;37:159-165.

19. Radosevich M, Goubran HA, Burnouf T. Fibrin sealants: scientific rationale, production methods, properties, and current clinical use. Vox Sang. 1997;72:133-143.

20. Schwartz O, Linnau Y, Loblich F, Seelich T. Tissue adhesive. US Patent. 1982;4:377-572.

21. Martinowitz U, Varon D, Jonas P, Bar-Maor A, Brenner B, Leibovitch I, Heim M. Circumcision in hemophilia: the use of fibrin glue for local hemostasis. J Urol. 1992;148(3):855-857.

22. Bar L, Malka O, Naboichenko E, Nur I. The binding of fibrin sealant to collagen is influenced by the method of purification and the crosslinked fibrinogen-fibronectin (heteronectin) content of the 'fibrinogen' component. Blood Coagul Fibrinolysis. 2005;16:111-117.

23. Wiseman D, Lyachovetsky Y, Keidan I, et al. The effect of tranexamic acid in fibrin sealant on adhesion formation in the rat. J Biomed Mater Res. 2004;68B:222-230.

24. Bussuttil RW. A comparison of antifibrinolytic agents used in hemostatic fibrin sealants. J Am Coll Surg. 2003;197:1021-1028.

25. Nur I, Routledge L, Lushkov G, et al. Absorption and elimination of alphathrombin and tranexamic acid after fibrin sealant application on resecate livers in rabbits. Blood Coagul Fibrinolysis. 1998;9: 533-537.
Clinical, Cosmetic and Investigational Dermatology

\section{Publish your work in this journal}

Clinical, Cosmetic and Investigational Dermatology is an international, peer-reviewed, open access, online journal that focuses on the latest clinical and experimental research in all aspects of skin disease and cosmetic interventions. All areas of dermatology will be covered; contributions will be welcomed from all clinicians and

\section{Dovepress}

basic science researchers globally. This journal is indexed on CAS The manuscript management system is completely online and includes a very quick and fair peer-review system, which is all easy to use. Visit http://www.dovepress.com/testimonials.php to read real quotes from published authors. 